\title{
Autosomal SNP typing of forensic samples with the GenPlex(TM) HID System: Results of a collaborative study
}

Tomas, C.; Axler-DiPerte, G.; Budimlija, Z.M.; Børsting, C.; Coble, M.D.; Decker, A.E.;

Eisenberg, A.; Fang, R.; Fondevila, M.; Fredslund, S. Frisk; Gonzalez, S.; Hansen, A.J.; HoffOlsen, P.; Haas, C.; Kohler, P.; Kriegel, A.K.; Lindblom, B.; Manohar, F.; Maroñas, O.;

Mogensen, H.S.; Neureuther, K.; Nilsson, H.; Scheible, M.K.; Schneider, P.M.; Sonntag, M.L.; Stangegaard, M.; Syndercombe-Court, D.; Thacker, C.R.; Vallone, P.M.; Westen, A.A.; Morling, N.

Published in:

Forensic Science International: Genetics

DOI:

doi:10.1016/j.fsigen.2010.06.007

Publication date:

2011

Citation for published version (APA):

Tomas, C., Axler-DiPerte, G., Budimlija, Z. M., Børsting, C., Coble, M. D., Decker, A. E., Eisenberg, A., Fang, R., Fondevila, M., Fredslund, S. F., Gonzalez, S., Hansen, A. J., Hoff-Olsen, P., Haas, C., Kohler, P., Kriegel, A. K., Lindblom, B., Manohar, F., Maroñas, O., ... Morling, N. (2011). Autosomal SNP typing of forensic samples with the GenPlex(TM) HID System: Results of a collaborative study. Forensic Science International: Genetics, 5(5), 369-375. https://doi.org/doi:10.1016/j.fsigen.2010.06.007 


\title{
Autosomal SNP typing of forensic samples with the GenPlex ${ }^{\mathrm{TM}}$ HID System: Results of a collaborative study
}

\author{
C. Tomas ${ }^{\text {a,* }}$, G. Axler-DiPerte ${ }^{\mathrm{b}}$, Z.M. Budimlija $^{\mathrm{b}}$, C. Børsting ${ }^{\mathrm{a}}$, M.D. Coble ${ }^{\mathrm{c}}$, A.E. Decker $^{\mathrm{d}}$, A. Eisenberg $^{\mathrm{e}}$, \\ R. Fang ${ }^{f}$, M. Fondevila ${ }^{g}$, S. Frisk Fredslund ${ }^{\text {a }}$, S. Gonzalez ${ }^{\text {e }}$, A.J. Hansen ${ }^{\text {a }}$, P. Hoff-Olsen ${ }^{\text {h }}$, C. Haas $^{\mathrm{i}}$, \\ P. Kohler ${ }^{\text {h }}$, A.K. Kriegel ${ }^{j}$, B. Lindblom ${ }^{k}$, F. Manohar ${ }^{f}$, O. Maroñas ${ }^{g}$, H.S. Mogensen ${ }^{a}$, K. Neureuther ${ }^{\text {, }}$, \\ H. Nilsson ${ }^{k}$, M.K. Scheible ${ }^{\text {c }}$, P.M. Schneider ${ }^{j}$, M.L. Sonntag ${ }^{1}$, M. Stangegaard ${ }^{\text {, }}$, \\ D. Syndercombe-Court ${ }^{\mathrm{m}}$, C.R. Thacker ${ }^{\mathrm{m}}$, P.M. Vallone ${ }^{\mathrm{d}}$, A.A. Westen $^{\mathrm{n}}{ }^{\mathrm{N}}$, N. Morling ${ }^{\mathrm{a}}$
}

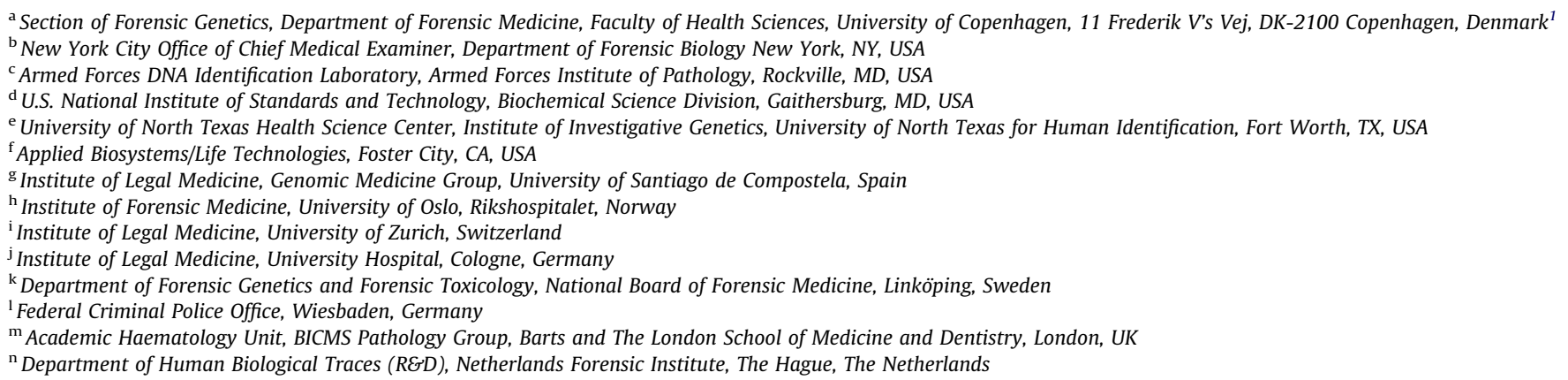

\section{A R T I C L E I N F O}

\section{Article history:}

Received 17 May 2010

Received in revised form 24 June 2010 Accepted 24 June 2010

\section{Keywords:}

GenPlex $^{\mathrm{TM}}$ HID

Autosomal SNPs

Forensic science

Degraded DNA

\begin{abstract}
A B S T R A C T
The GenPlex ${ }^{\mathrm{TM}}$ HID System (Applied Biosystems - AB) offers typing of 48 of the 52 SNPforID SNPs and amelogenin. Previous studies have shown a high reproducibility of the GenPlex ${ }^{\mathrm{TM}}$ HID System using $250-$ $500 \mathrm{pg}$ DNA of good quality. An international exercise was performed by 14 laboratories ( 9 in Europe and 5 in the US) in order to test the robustness and reliability of the GenPlex ${ }^{\mathrm{TM}}$ HID System on forensic samples. Three samples with partly degraded DNA and 10 samples with low amounts of DNA were analyzed in duplicates using various amounts of DNA. In order to compare the performance of the GenPlex ${ }^{\mathrm{TM}} \mathrm{HID}$ System with the most commonly used STR kits, 500 pg of partly degraded DNA from three samples was typed by the laboratories using one or more STR kits. The median SNP typing success rate was $92.3 \%$ with $500 \mathrm{pg}$ of partly degraded DNA. Three of the fourteen laboratories counted for more than two thirds of the locus dropouts. The median percentage of discrepant results was $0.2 \%$ with $500 \mathrm{pg}$ degraded DNA. An increasing percentage of locus dropouts and discrepant results were observed when lower amounts of DNA were used. Different success rates were observed for the various SNPs. The rs763869 SNP was the least successful. With the exception of the MiniFiler ${ }^{\mathrm{TM}}$ kit (AB), GenPlex ${ }^{\mathrm{TM}}$ HID performed better than five other tested STR kits. When partly degraded DNA was analyzed, GenPlex ${ }^{\mathrm{TM}}$ HID showed a very low mean mach probability, while all STR kits except MiniFiler ${ }^{\mathrm{TM}}$ had very limited discriminatory power.
\end{abstract}

( 2010 Elsevier Ireland Ltd. All rights reserved.

\section{Introduction}

The usefulness of SNP typing in forensic genetics has previously been pointed out in several publications [1-3]. Short DNA fragments

\footnotetext{
* Corresponding author. Tel.: +45 35326283; fax: +45 35326270.

E-mail address: carmen.tomas@forensic.ku.dk (C. Tomas).

1 The SNPforID Consortium.
}

with SNPs can be amplified, which makes it possible to analyze SNPs in partly degraded DNA samples [1,2,4]. Moreover, the low mutation rate of SNPs is an important advantage in kinship analysis [3]. The SNPforID consortium [5] selected 52 biallelic SNP markers with high levels of polymorphism in the major population groups [1]. Short amplicons (up to $115 \mathrm{bp}$ ) were used to analyze the 52 SNPs and the mean match probability was at least $5.0 \times 10^{-19}$. Several platforms can be used to analyze SNPs [6-10]. The most widely used assay is the single base extension (SBE) assay using the SNaPshot ${ }^{\mathbb{R}}$ kit 
(AB: Applied Biosystems, Foster City, CA, USA) because it is easy to implement in forensic genetic laboratories. The SBE-based SNP typing assay of the SNPforID 52-plex was validated for forensic genetic investigations [4] and it performed better than the most commonly used STR kits when partly degraded DNA samples were investigated [2,4]. Nevertheless, the unspecific addition of $\mathrm{dA}$ nucleotides at the end of the PCR products by the Taq polymerase [11] and the fact that the signal strength of the four colours in the SNaPshot ${ }^{\circledR}$ kit $(A B)$ is unbalanced makes the interpretation of the results challenging [12].

Applied Biosystems developed the GenPlex ${ }^{\mathrm{TM}}$ HID System using 48 of the 52 SNPs in the SNPforID 52-plex and amelogenin. The GenPlex $^{\mathrm{TM}}$ HID protocol is based on the SNPplex ${ }^{\mathrm{TM}}$ assay [13] but in this case, the protocol starts with a PCR reaction, which makes the method more sensitive and suitable for forensic applications. The GenPlex ${ }^{\mathrm{TM}}$ HID protocol contains a large number of pipetting steps that makes it laborious and time consuming. However, the use of a simple robot reduces the laboriousness of the protocol [14]. A limited number of laboratories have successfully tested the GenPlex $^{\mathrm{TM}}$ HID System $[15,16]$ and demonstrated that it is a sensitive and reproducible SNP typing method when good quality samples are analyzed.

In order to test the performance of the GenPlex ${ }^{\mathrm{TM}}$ HID System in challenging forensic genetic samples, as well as the handling of a complex typing protocol in routine casework laboratories, an international exercise was organized within the framework of the EDNAP and ENFSI groups. Fourteen laboratories ( 9 in Europe and 5 in the USA) participated in the exercise and 13 DNA samples (three naturally degraded DNA samples from case work and 10 DNA samples from blood from healthy donors) were SNP typed using the GenPlex ${ }^{\mathrm{TM}}$ HID System at various DNA concentrations. The results of the GenPlex ${ }^{\text {TM }}$ HID System were compared to the results obtained by typing $500 \mathrm{pg}$ of partly degraded DNA with six commonly used STR kits.

\section{Material and methods}

\subsection{DNA samples}

Three DNA extracts from cadaveric remains (paraffinembedded tissue, nails and blood) with partly degraded DNA that gave partial STR profiles with the AmpF $\ell$ STR ${ }^{\circledR}$ SGM Plus ${ }^{\circledR}$ PCR amplification kit $(A B)$ were selected. None of the partly degraded DNA samples showed STR results corresponding to amplicons longer than $185 \mathrm{bp}$, weak results were obtained with amplicons between $135 \mathrm{bp}$ and $185 \mathrm{bp}$ and strong results were observed with amplicons lower than $135 \mathrm{bp}$. In addition, DNA was extracted from blood collected from 10 healthy volunteers.
All samples were investigated in quadruplicate by the organizing laboratory using the GenPlex ${ }^{\mathrm{TM}}$ HID System $(\mathrm{AB})$ and the SBE-based 49plex SNP assay [12]. Concordant results were obtained from at least two of the investigations. The results obtained by the organizing laboratory were used as reference.

The protocols were approved by the Danish ethical committee (KF-01-037/03).

\subsection{DNA extraction and quantification}

DNA from the three samples with partly degraded DNA was extracted using a standard phenol-chloroform procedure. DNA from blood samples from 10 healthy donors was extracted from $15 \mu \mathrm{L}$ of blood using the MagAttract DNA blood midi M48 kit (Qiagen GmbH, Hilden, Germany) and a Tecan Freedom EVO ${ }^{\mathbb{B}}$ robot (Tecan trading AG, Switzerland) [17]. The DNA samples were quantified with the Quantifiler ${ }^{\mathbb{R}}$ Human DNA Quantitation kit (AB) using an $A B 7900(A B)$ real time PCR analyzer according to the manufacturer's recommendations.

\subsection{Shipment of samples and reagents}

DNA extracts and the critical reagents needed for SNP typing with the GenPlex ${ }^{\mathrm{TM}}$ HID System (AB) were sent on dry ice by courier to the participating laboratories.

\subsection{GenPlex ${ }^{T M}$ HID SNP typing}

The participating laboratories typed the degraded DNA samples in duplicate with the GenPlex ${ }^{\mathrm{TM}}$ HID System using 500 pg, $250 \mathrm{pg}$, 100 pg, $50 \mathrm{pg}$ and $20 \mathrm{pg}$ of DNA in the PCR reaction. Ten blood DNA extracts were SNP typed in duplicate by the participating laboratories with the GenPlex ${ }^{\mathrm{TM}}$ HID System adding $50 \mathrm{pg}$, $25 \mathrm{pg}, 10 \mathrm{pg}, 5 \mathrm{pg}$ and $2 \mathrm{pg}$ of DNA to the PCR reaction. The DNA titrations were prepared by each participating laboratory.

Details on the GenPlex ${ }^{\mathrm{TM}}$ HID procedure are published elsewhere [15]. Briefly, a multiplex PCR reaction was performed using $2 \mu \mathrm{L}$ of DNA with amounts indicated above. All laboratories performed the PCR reaction in a GeneAmp ${ }^{\mathbb{R}}$ PCR System 9700 thermal cycler (AB) according to the manufacturer's recommendations. Leftover primers and unused dNTPs were removed from the PCR products using $2 \mu \mathrm{L}$ of ExoSAP-IT ${ }^{\circledR}$ (USB Corp., Cleveland, OH, USA). An oligo ligation assay (OLA) was performed using the PCR products as templates. The OLA assay required the phosphorylation of the oligos. This may be performed at the same time as the OLA assay or as a step preceding the OLA assay. Twelve of the fourteen participating laboratories phosphorylated the oligos prior to the OLA assay, while two of them performed the phosphorylation reaction and the OLA assay in a single step (Table 1 ). All the

Table 1

Details of the GenPlex ${ }^{\mathrm{TM}}$ HID protocol.

\begin{tabular}{|c|c|c|c|c|c|}
\hline Lab \# & $\begin{array}{l}\text { Previous experience } \\
\text { with GenPlex }\end{array}$ & $\mathrm{ABI}$ sequencer & $\begin{array}{l}\text { No. of steps in } \\
\text { the OLA reaction }\end{array}$ & OLA product $(\mu \mathrm{L})$ & $\begin{array}{l}\text { Sample loading } \\
\text { reagent }(\mu \mathrm{L})\end{array}$ \\
\hline 1 & Yes & $3130 x l$ & 2 & 10 & 17.5 \\
\hline 2 & Yes & 3130 & 2 & 5 & 10 \\
\hline 3 & Yes & 3730xl & 2 & 10 & 17.5 \\
\hline 4 & No & $3130 x \mathrm{l}$ & 2 & 10 & 10 \\
\hline 5 & No & 3130xl & 2 & 10 & 10 \\
\hline 6 & No & $3130 x \mathrm{l}$ & 2 & 5 & 10 \\
\hline 7 & Yes & $3130 x \mathrm{l}$ & 1 & 5 & 10 \\
\hline 8 & Yes & $3130 x \mathrm{x}$ & 1 & 10 & 10 \\
\hline 9 & No & $3130 x \mathrm{l}$ & 2 & 10 & 17.5 \\
\hline 10 & No & $3130 x \mathrm{l}$ & 2 & 10 & 17.5 \\
\hline 11 & Yes & $3130 x l$ & 2 & $5-10$ & $10-17.5$ \\
\hline 12 & Yes & $3130 x \mathrm{l}$ & 2 & 5 & 10 \\
\hline 13 & No & $3130 x \mathrm{l}$ & 2 & 10 & 10 \\
\hline 14 & Yes & $3130 x \mathrm{x}$ & 2 & 10 & 17.5 \\
\hline
\end{tabular}


participating laboratories performed the OLA assay in a GeneAmp $^{\circledR}$ PCR System 9700 thermalcycler (AB) according to the manufacturer's recommendations. Five or ten microliters of biotinylated OLA products (Table 1 ) were added to a streptavidin coated capture microtitre plate (AB). Hybridization of ZipChute ${ }^{\circledR}$ probes was performed on the captured OLA products. A volume of $10 \mu \mathrm{L}$ or $17.5 \mu \mathrm{L}$ of sample loading reagent (AB) was used to elute the ZipChute ${ }^{\circledR}$ probes (Table 1). Twelve of the fourteen laboratories used an $A B I 3130 x l$ Genetic Analyzer $(A B)$ to separate the eluted ZipChute ${ }^{\circledR}$ probes. One laboratory used an ABI 3130 (AB) and one laboratory used an ABI 3730xl (AB) (Table 1). All laboratories used POP- ${ }^{\mathrm{TM}}$ polymer $(\mathrm{AB})$, and all laboratories used $36 \mathrm{~cm}$ capillaries except for one that used $50 \mathrm{~cm}$ capillaries. Capillaries that had not previously been used were pre-conditioned using a pre-conditioning kit $(\mathrm{AB})$.

\subsection{STR typing}

In order to compare the efficiencies of the GenPlex ${ }^{\mathrm{TM}}$ HID System and STR kits on degraded DNA samples, all laboratories typed 500 pg of partly degraded DNA samples in duplicates with one or more of the following STR kits: Identifiler ${ }^{\mathrm{TM}}(\mathrm{AB})$ [6 laboratories], SGM Plus ${ }^{\mathrm{TM}}(\mathrm{AB})$ [5 laboratories], SEfiler Plus ${ }^{\mathrm{TM}}(\mathrm{AB})$ [3 laboratories], MiniFiler ${ }^{\mathrm{TM}}(\mathrm{AB})$ [2 laboratories], PowerPlex $16^{\mathbb{}}{ }^{\mathrm{B}}$ (PP16) (Promega) [2 laboratories], PowerPlex ES ${ }^{\circledR}$ (PPES) (Promega) [1 laboratory], according to the usual procedures of the laboratories.

\subsection{Data collection}

All the results were collected and analyzed by the organizing laboratory. GeneMapper ${ }^{\mathrm{TM}} 4.0(\mathrm{AB})$ was used to call peaks higher than 10 relative fluorescent units (RFUs) and the results were further analyzed using Excel@ (Microsoft). In house criteria for allele calling were established. Peak heights lower than 10 RFUs were classified as "not amplified". Peak heights below 100 RFUs for presumed homozygous loci and below 50 RFUs for presumed heterozygous loci were classified as "weak". All systems that were classified as "not amplified" or "weak" were considered as locus dropouts. Peak height ratios were calculated for each genotype by dividing the higher peak height by the lower peak height. Unbalanced peak height ratios (ratios between 7.0 and 12.0) were classified as "uncertain assignments". Heterozygotes were identified when the peak height ratio was less than $7: 1$. Homozygotes were identified when the peak height ratio was greater than 12:1.

The success rate was defined by the proportion of reported SNP types that were identical to the reference genotypes. Discrepant results were defined by the number of SNP types that were not identical to the reference genotypes. Three kinds of discrepancies were observed: (i) allele dropout (heterozygous loci that only showed one of the two expected peaks), (ii) allele drop-in (homozygous loci that showed two peaks; one corresponding to the real allele and a spurious peak), and (iii) allele dropout plus allele drop-in (apparent homozygous loci with one peak that did not correspond to the real allele).

The data were grouped and analyzed in two ways. First, all the data generated by each participating laboratory were collected, analyzed and compared to the reference genotypes (i.e. 89,180 SNP types corresponding to 49 SNPs from 13 samples analyzed in duplicates by 14 laboratories using 5 DNA dilutions). Second, consensus SNP types were obtained from the duplicated investigations reported by each laboratory (i.e. 44,590 intra-laboratory consensus SNP types). The intra-laboratory consensus SNP types were compared with the reference genotypes.

SNP and STR profiles obtained from $500 \mathrm{pg}$ of degraded DNA were compared by calculating percentages of full profiles, i.e. number of alleles observed in relation to the maximum number of alleles that are present in a full profile.

\subsection{Statistical analysis}

The results were further analyzed using box and whisker plots with the SPSS statistical package (SPSS Inc., Chicago, IL, USA). The box and whisker plot summarizes the overall range of the data graphically. Five values are used to construct a box and whisker plot: (1) the mean value (represented by an horizontal line that divides the box), (2) the first quartile (the bottom of the box), (3) the third quartile (the top of the box); the length of the box (distance between the first and the third quartiles) is the interquartile range (IQR), (4) the 'maximum value', up to $1.5 \mathrm{IQRs}$ from the top of the box (represented by a whisker) and (5) the 'minimum value', up to 1.5 IQRs from the bottom of the box (represented by a whisker). Values that were between 1.5 and 3 IQRs from the end of
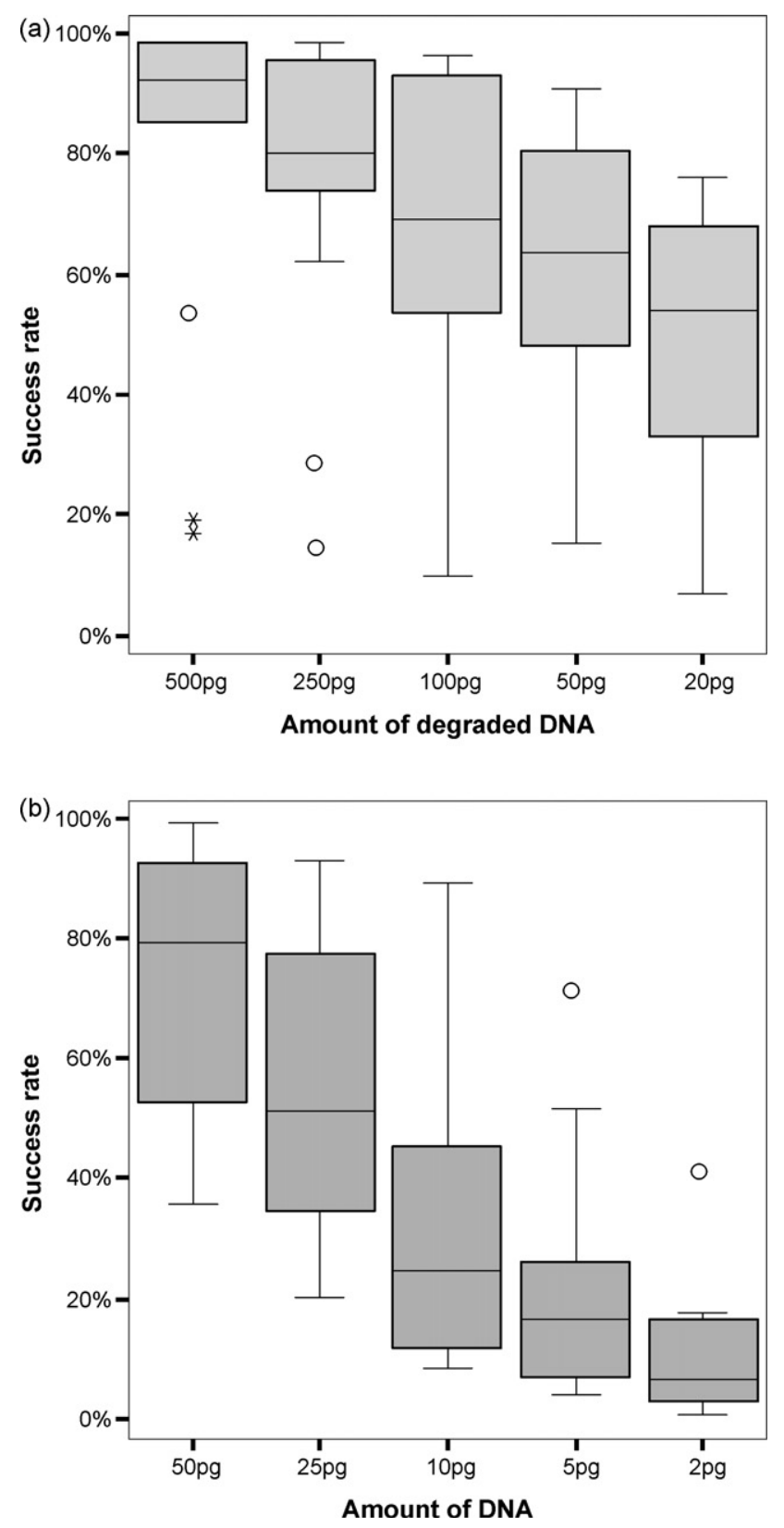

Fig. 1. Box-plot of the success rates of the GenPlex ${ }^{\mathrm{TM}}$ HID System typing results reported by 14 laboratories. Degraded DNA (a) and DNA from blood samples (b). 
a box are called extreme values and were represented by circles. Outliers were defined by the values that were more than 3 IQRs from the end of the box and were represented by asterisks.

In order to compare the results obtained with the GenPlex ${ }^{\mathrm{TM}}$ HID System and the various STR kits, a median Polish analysis [18] was performed using the statistical software Minitab ${ }^{\mathrm{TM}} 15$.

\section{Results and discussion}

\subsection{The reported results: success rates and discrepant results}

The 14 laboratories reported 3377 SNP types (82\%) with 500 pg of partly degraded DNA from the three samples. The success rate ranged from $15.6 \%$ to $98.6 \%$ (median: $92.3 \%$ ) among the 14 laboratories (Supplementary material 1). Laboratories \# 3, 4 and 9 showed success rates clearly lower than the average of the other 11
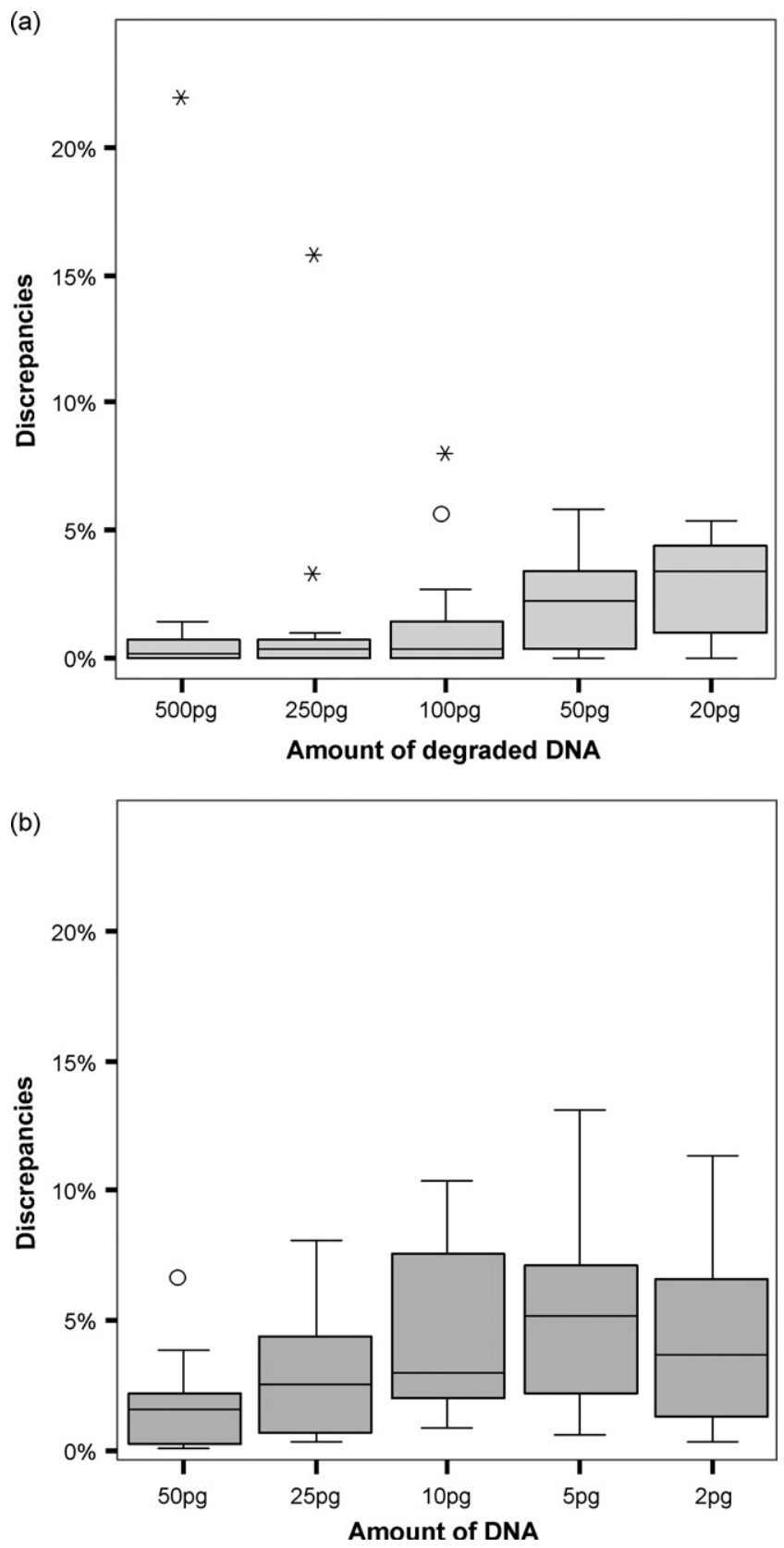

Fig. 2. Box-plot of the discrepant results observed in the results reported by the 14 laboratories typing various amounts of degraded DNA (a) and DNA from blood samples (b) with the GenPlex ${ }^{\mathrm{TM}}$ HID System. laboratories. If the results from laboratories 3, 4 and 9 were not taken into account, an overall percentage of $94.6 \%$ of the expected SNP types were reported with an overall success rate of $94.2 \%$ (Supplementary material 1 ). The low success rate reported by laboratories 3, 4 and 9 can mainly been explained by technical problems experienced by the three laboratories during the analysis of the samples (e.g. evaporation of the PCR products and prolonged waiting time between the various protocol steps). Although the GenPlex $^{\mathrm{TM}}$ HID protocol was not considered complicated by the participating laboratories, multiple steps made the process laborious and time consuming. All laboratories performed the protocol manually. As previously discussed [14,16], the use of a robot decreases the laboriousness of the protocol and would most likely increase the success rate. The success rate decreased when less than 500 pg of DNA was used in the PCR reaction (Fig. 1a). With the exception of laboratory \# 9, low percentages of discrepant
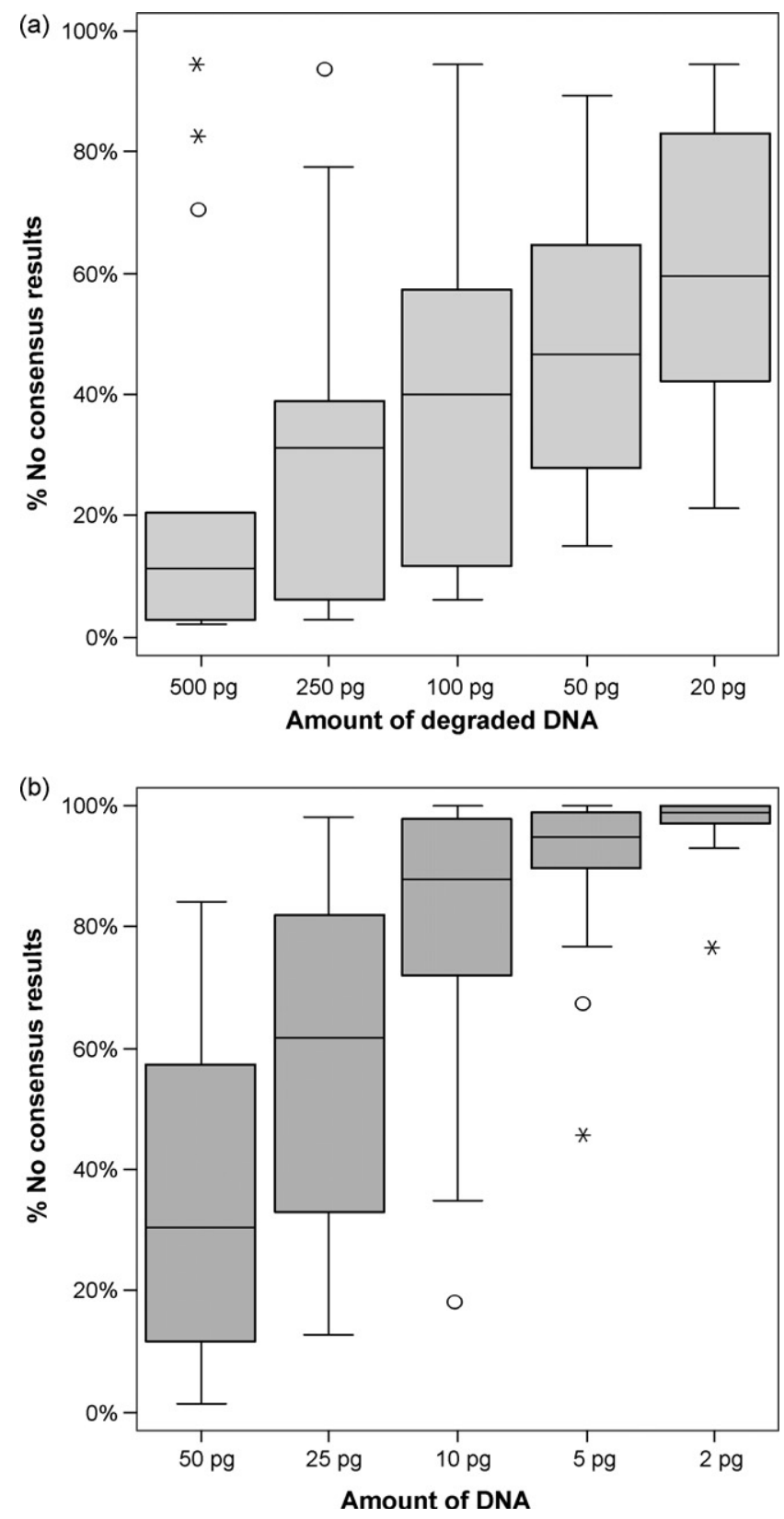

Fig. 3. Box-plot of the percentage of intra-laboratory results with no consensus SNP types reported by the 14 laboratories typing various amounts of degraded DNA (a) and DNA from blood samples (b) with the GenPlex ${ }^{\mathrm{TM}}$ HID System. 
results were reported when 500 pg of partly degraded DNA was analyzed (median: $0.2 \%$, Supplementary material 1 ). After a closer analysis of the results reported by laboratory 9 , we suspect that this laboratory switched two of the DNA samples (degraded samples 2 and 3). Low numbers of discrepant results were observed with $500 \mathrm{pg}$ and $250 \mathrm{pg}$ DNA, but it increased with $100 \mathrm{pg}$ and less DNA reaching a median value of $3.4 \%$ with $20 \mathrm{pg}$ of DNA (Fig. 2a).

For the 10 blood DNA samples, 10,370 SNP types (75.6\%) were reported by the 14 laboratories for 50 pg of DNA (Supplementary material 2). The success rate decreased with smaller amounts of DNA (Fig. 1b) not only due to an increasing number of locus dropouts, but also due to an increasing proportion of discrepant SNP types (Fig. 2b). Thus, the use of small amounts of DNA strongly decreased the reliability of the results. When 5 pg DNA was used, $5.3 \%$ of the results were discrepant. This value decreased when $2 \mathrm{pg}$ of DNA was used due to the few data reported for $2 \mathrm{pg}$ of DNA.

\subsection{The unreported results: locus dropouts and uncertain assignments}

When 500 pg of partly degraded DNA was analyzed, 739 SNP types (18\%) were not reported. Uncertain SNP typing results were observed in $1.6 \%$ of the results and $16.4 \%$ of the SNP loci dropped out (Supplementary material 1). The number of uncertain assignments could most likely be decreased by adjusting the SNP calling criteria. Nevertheless, this is only possible for laboratories that routinely use the GenPlex ${ }^{\mathrm{TM}}$ HID System. Three of the fourteen laboratories (labs \# 3, 4 and 9) counted for more than two thirds of the locus dropouts. If the results of these three laboratories were removed, the overall number of locus dropouts decreased from $16.4 \%$ to $3.8 \%$ in the remaining 11 laboratories (Supplementary material 1 ). In these 11 laboratories, the percentage of locus dropouts observed with $500 \mathrm{pg}$ of DNA ranged from $0 \%$ (observed three times) to $11.9 \%$ (median: $1 \%$ ). The

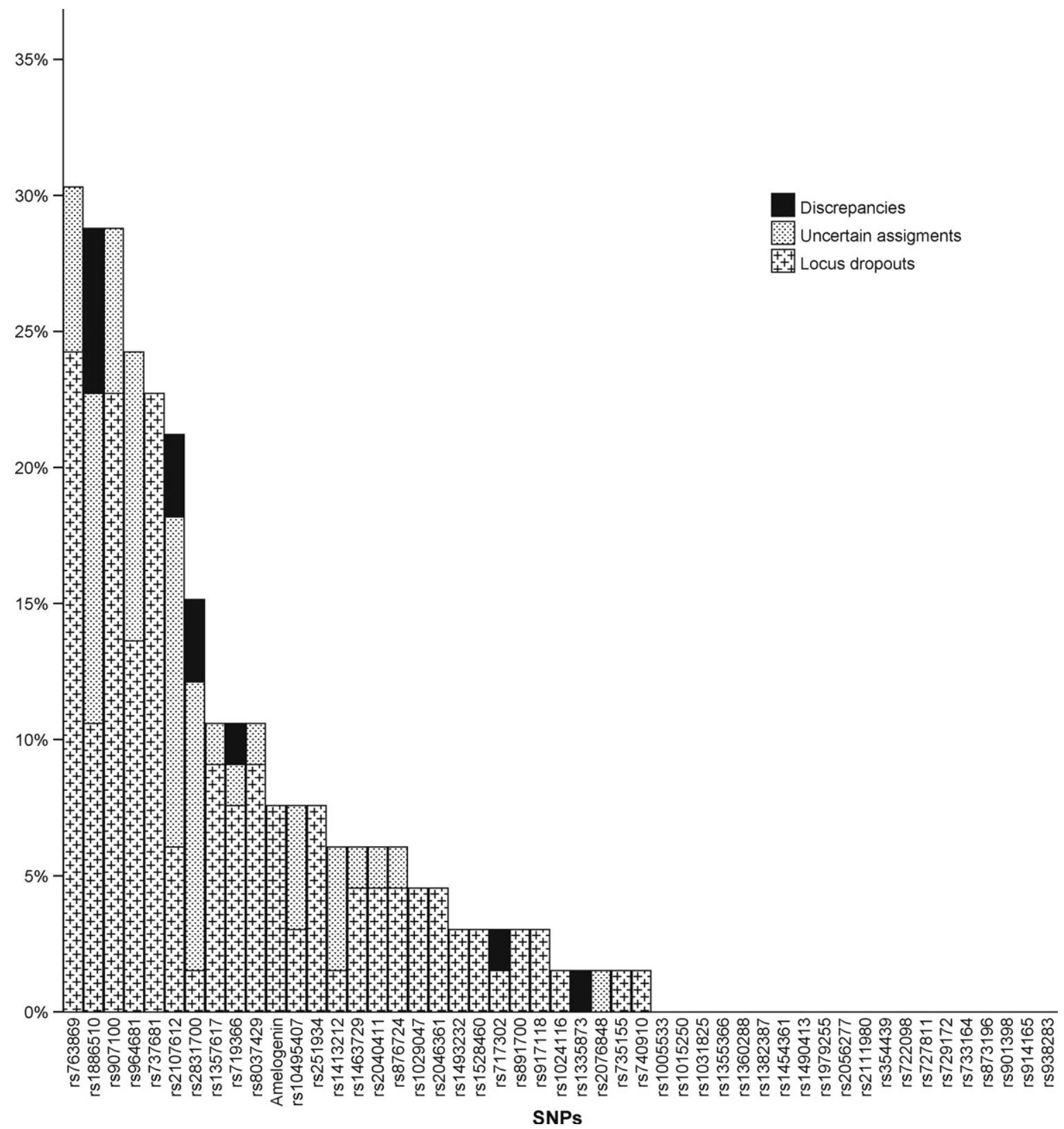

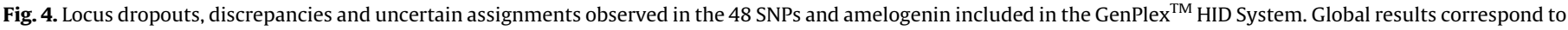
the analysis of $500 \mathrm{pg}$ of degraded DNA by 11 of the 14 participating laboratories. Results reported by laboratories 3,4 and 9 were not included. 
number of unreported results was increased to 2024 (49.2\%) with 20 pg DNA.

For the 10 blood DNA samples, the total number of unreported results varied from $24.4 \%$ with $50 \mathrm{pg}$ DNA (Supplementary material 2) to $85.7 \%$ with 2 pg DNA. With 50 pg DNA, locus dropouts were observed in $22.3 \%$ of the results, while uncertain assignments represented $2.1 \%$ of the results. There was a large variation in the amount of locus dropouts reported by each laboratory (0.1-62.3\%; median: $16.3 \%$; Supplementary material 2), most likely due to the stochastic effect of the use of small amounts of DNA in the PCR reaction [19].

\subsection{Analysis of consensus SNP types}

We tested the intra-laboratory reproducibility of the results by comparing the duplicated runs reported by each participating laboratory. Fig. 3 represents the percentage of intra-laboratory results with no consensus SNP types. In most part of the cases, an intra-laboratory consensus was not reached due to the lack of results in one or two runs. Less often, it was due to discrepant results. A maximum number of 2058 consensus SNP types were expected with $500 \mathrm{pg}$ of degraded DNA and a total number of 1557 consensus SNP types were obtained (75.7\%). If the results of laboratories 3, 4 and 9 were removed, intra-laboratory consensus SNP types were reached in $91.2 \%$ of the SNP types. A total of 20 inter-laboratory discrepancies (1\%) were observed if all 14 laboratories were considered, but only two $(0.1 \%)$ if the 11 laboratories were taken into account. With the 10 blood DNA samples, 4366 consensus SNP types (63.6\%) were obtained with $50 \mathrm{pg}$ DNA. Intra-laboratory discrepancies increased with lower amounts of DNA in the same way as did the inter-laboratories discrepancies.

\subsection{Performance of the various SNPs in the GenPlex ${ }^{T M}$ HID System}

The performance of the various SNP loci was analyzed using the results that showed the highest success rates (results from $500 \mathrm{pg}$ degraded DNA). The results reported by laboratories 3, 4 and 9 were not taken into account due to their poor quality. Fig. 4 shows the percentage of locus dropouts, uncertain assignments and discrepant results observed for each SNP. Twenty out of the 49 loci in the GenPlex ${ }^{\mathrm{TM}}$ HID System showed success rates of $100 \%$ and the lowest success rate was $69.7 \%$ (rs763869). Locus dropout was the main cause of unsuccessful results but, in 7 of the SNPs, the percentage of uncertain results and discrepancies was higher than that of locus dropouts. Discrepant results were observed in six of the 49 SNP loci (rs1886510, rs2107612, rs2831700, rs719366, rs717302, and rs1335873), and in all but one (rs1335873) the discrepancies were due to allele drop-ins. The SNP typing of some of the loci (especially rs1886510, rs2107612 and rs2831700) was less reliable due to the presence of a spurious peak that did not correspond to the real allele. As

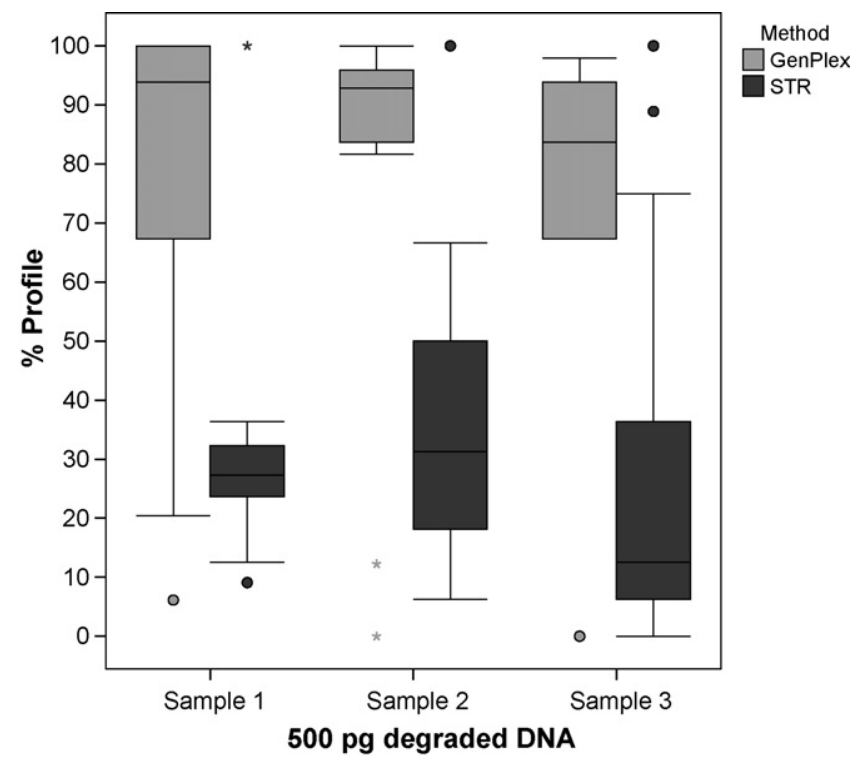

Fig. 5. Percentage of profiles obtained by analyzing $500 \mathrm{pg}$ of degraded DNA with GenPlex ${ }^{\mathrm{TM}}$ HID and several STR kits (see Section 2 for details).

mentioned above, the SNP assignment of some of the loci could probably be improved by a re-adjustment of the allele calling criteria, but not all uncertain and discrepant results could be corrected in this way. A previous study [16] showed a poorer performance of some of the SNPs in the GenPlex ${ }^{\mathrm{TM}}$ HID System, especially rs907100, and an improvement of the GenPlex ${ }^{\mathrm{TM}}$ HID protocol was suggested. Based on the results of the present study, an improvement in the protocol is still needed, mainly in order to balance the reactions and avoid locus dropouts and spurious peaks that may simulate real alleles.

\subsection{GenPlex ${ }^{T M}$ HID results vs. STR results}

The 14 participating laboratories analyzed $500 \mathrm{pg}$ of three partly degraded DNA samples in duplicates using one or more STR kits in order to compare the performance of the GenPlex ${ }^{\mathrm{TM}}$ HID System with the most commonly used STR kits. The percentages of consensus profiles were calculated (Fig. 5) and the median polish results were used to compare the success rates of the various systems. Table 2 shows the results of the median polish analysis for each kit (common effect of samples and laboratories). With the exception of MiniFiler ${ }^{\mathrm{TM}}(\mathrm{AB}), \mathrm{GenPlex}^{\mathrm{TM}}$ HID performed better than the other five STR kits showing a median percentage profile of $91.3 \%$. Although the MiniFiler ${ }^{\mathrm{TM}}$ kit showed good results, the partial profiles obtained with the GenPlex $^{\mathrm{TM}}$ HID System were more informative than the results obtained with MiniFiler ${ }^{\mathrm{TM}}$ (Table 2). The SEfiler Plus ${ }^{\mathrm{TM}}$ kit (AB)

Table 2

Percentage of DNA profiles obtained by analyses of 500 pg degraded DNA with the GenPlex ${ }^{\text {TM }}$ HID System and six STR kits.

\begin{tabular}{|c|c|c|c|c|c|}
\hline Kit & $\begin{array}{l}\text { \% Profiles } \\
\text { (median Polish) }\end{array}$ & $\begin{array}{l}\text { Number of } \\
\text { laboratories }\end{array}$ & $\begin{array}{l}\text { Number of } \\
\text { PCR cycles }\end{array}$ & $\begin{array}{l}\text { Mean match probability } \\
\text { (US Caucasians) }\end{array}$ & $\begin{array}{l}\text { "Partial" match } \\
\text { probability }^{* *}\end{array}$ \\
\hline GenPlex & 91.3 & 14 & 30 & $9.60 \times 10^{-18^{*}}$ & $3.12 \times 10^{-16}$ \\
\hline MiniFiler & 100.0 & 2 & 30 & $8.21 \times 10^{-11}$ & $8.21 \times 10^{-11}$ \\
\hline SEfiler & 41.7 & 3 & 30 & $7.46 \times 10^{-14}$ & $1.67 \times 10^{-05}$ \\
\hline SGM Plus & 27.3 & 5 & 28 & $2.99 \times 10^{-13}$ & $3.10 \times 10^{-03}$ \\
\hline PP16 & 25.0 & 2 & 32 & $5.46 \times 10^{-18}$ & $3.53 \times 10^{-04}$ \\
\hline PPES & 22.2 & 1 & 32 & $1.69 \times 10^{-11}$ & $4.53 \times 10^{-02}$ \\
\hline Identifiler & 15.6 & 6 & 28 & $5.01 \times 10^{-18}$ & $1.88 \times 10^{-02}$ \\
\hline
\end{tabular}

" Europeans.

*** Approximate match probabilities of partial profiles were obtained by assuming equal match probabilities of all the systems in a kit. 
showed the best results after MiniFiler ${ }^{\mathrm{TM}}$ and the GenPlex ${ }^{\mathrm{TM}}$ HID System.

\section{Conclusions}

Partial but reproducible SNP profiles were obtained from $250 \mathrm{pg}$ to $500 \mathrm{pg}$ naturally degraded DNA using the GenPlex ${ }^{\mathrm{TM}}$ HID System in 11 of 14 laboratories. Three of the 14 participating laboratories encountered technical problems during the typing process. Due to the limited amount of samples and reagents available for this study, it was not possible for these laboratories to repeat the investigations. The quality of the results reported by the laboratories was not related to their experience with the GenPlex ${ }^{\mathrm{TM}}$ HID protocol or to small alterations in the protocol (e.g. the phosphorylation step). With the exception of the MiniFiler ${ }^{\mathrm{TM}}$ kit, the GenPlex ${ }^{\mathrm{TM}}$ HID System performed better than the tested STR kits, although the lower match probability was obtained with the GenPlex ${ }^{\mathrm{TM}}$ HID System. The GenPlex ${ }^{\mathrm{TM}}$ HID protocol is a laborious and time consuming method but it is not difficult to implement in practice since most standard forensic genetic laboratories already have the great majority of the necessary equipment. The results obtained in this collaborative exercise shows that the GenPlex ${ }^{\mathrm{TM}}$ HID method is a reliable method for SNP typing also when partly degraded samples are analyzed. Nevertheless, still some optimization is required in order to avoid locus dropouts, allele drop-ins and allele dropouts. Most likely an improvement of the PCR and/or OLA reactions will be needed to obtain a better balance of the heights of the peaks of the various SNP markers. As previously suggested, an improvement in the SNP allele calling method implemented in the GeneMapper ${ }^{\mathrm{TM}}$ software would also facilitate the SNP typing.

\section{Acknowledgments}

We thank Nadia Jochumsen, Gabi Föster, Stephan Walker for excellent technical assistance and Mechthild Prinz, Andreas Tillmar, Rebecca Just for help during the laboratory investigations and preparation of the manuscript. The authors thank the American Registry of Pathology for administrative support. The work was supported by Ellen and Aage Andersen's Foundation. The opinions and assertions contained herein are those of the authors and are not to be construed as views of the U.S. Government.

\section{Appendix A. Supplementary data}

Supplementary data associated with this article can be found, in the online version, at doi:10.1016/j.fsigen.2010.06.007.

\section{References}

[1] J.J. Sanchez, C. Phillips, C. Børsting, K. Balogh, M. Bogus, M. Fondevila, C.D. Harrison, E. Musgrave-Brown, A. Salas, D. Syndercombe-Court, P.M. Schneider, A. Carracedo, N. Morling, A multiplex assay with 52 single nucleotide polymorphisms for human identification, Electrophoresis 27 (2006) 1713-1724.

[2] J.J. Sanchez, C. Børsting, K. Balogh, B. Berger, M. Bogus, J.M. Butler, A. Carracedo, D. Syndercombe Court, L.A. Dixon, B. Filipović, M. Fondevila, P. Gill, C.D. Harrison, C. Hohoff, R. Huel, B. Ludes, W. Parson, T.J. Parsons, E. Petkovski, C. Phillips, H. Shcmitter, P.M. Schneider, P.M. Vallone, N. Morling, Forensic typing of autosomal SNPs with a 29 SNP-multiplex - results of a collaborative EDNAP exercise, Forensic Sci. Int. Genet. 2 (2008) 176-183.

[3] C. Børsting, J.J. Sanchez, H.E. Hansen, A.J. Hansen, H.Q. Bruun, N. Morling, Performance of the SNPforID 52-plex assay in paternity testing, Forensic Sci. Int. Genet. 2 (2008) 292-300.

[4] E. Musgrave-Brown, D. Ballard, K. Balogh, K. Bender, B. Berger, M. Bogus, C. Børsting, M. Brion, M. Fondevila, C. Harrison, C. Oguzturun, W. Parson, C. Phillips, C. Proff, E. Ramos-Luis, J.J. Sanchez, P. Sanchez-Diz, B. Sobrino-Rey, B. StradmannBellinghausen, C. Tacker, A. Carracedo, N. Morling, R. Scheithauer, P.M. Schneider, D. Syndercombe-Court, Forensic validation of the SNPforID 52-plex assay, Forensic Sci. Int. Genet. 1 (2007) 186-190.

[5] The SNPforID consortium, http://www.snpforid.org.

[6] J. Mengel-Jørgensen, J.J. Sanchez, C. Børsting, F. Kirpekar, N. Morling, Typing of multiple SNPs using ribonuclease cleavage of DNA/RNA chimeric single base extension primers and detection by MALDI-TOF mass spectrometry, Anal. Chem. 77 (2005) 5229-5235.

[7] C. Børsting, J.J. Sanchez, N. Morling, SNP typing on the NanoChip electronic microarray, Methods Mol. Biol. 297 (2005) 155-168.

[8] C. Harrison, E. Musgrave-Brown, K. Bender, A. Carracedo, N. Morling, P. Schneider D. Syndercombe-Court, A sensitive issue: pyrosequencing as a valuable forensic SNP typing platform, Int. Congr. Ser. 1288 (2006) 52-54.

[9] B. Sobrino, M. Lareu, M. Brion, A. Carracedo, SNP genotyping with single base extension-tag microarrays, Int. Congr. Ser. 1261 (2004) 331-333.

[10] K. Krjutškov, T. Viltrop, P. Palta, E. Metspalu, E. Tamm, S. Suvi, K. Sak, A. Merilo, H. Sork, R. Teek, T. Nikopensius, T. Kivisild, A. Metspalu, Evaluation of the 124-plex SNP typing microarray for forensic testing, Forensic Sci. Int. Genet. 4 (2009) 43-48.

[11] V.L. Magnuson, D.S. Ally, S.J. Nylund, Z.E. Karanjawala, J.B. Rayman, J.I. Knapp, A.L. Lowe, S. Ghosh, F.S. Collins, Substrate nucleotide-determined non-templated addition of adenine by Taq DNA polymerase: implications for PCR-based genotyping and cloning, Biotechniques 21 (1996) 700-709.

[12] C. Børsting, E. Rockenbauer, N. Morling, Validation of a single nucleotide polymorphism (SNP) typing assay with 49 SNPs for forensic genetic testing in a laboratory accredited according to the ISO 17025 standard, Forensic Sci. Int. Genet. 4 (2009) 34-42.

[13] AB SNPlex ${ }^{\mathrm{TM}}$ chemistry guide pdf, http://docs.appliedbiosystems.com/pebiodocs/ 04360856.pdf.

[14] M. Stangegaard, C. Tomas, A.J. Hansen, R. Frank-Hansen, C. Børsting, N. Morling, Biomek-3000 and GenPlex SNP genotyping in forensic genetics, JALA 13 (5) (2008) 297-303.

[15] C. Phillips, R. Fang, D. Ballard, M. Fondevila, C. Harrison, F. Hyland, E. MusgraveBrown, C. Proff, E. Ramos-Luis, B. Sobrino, A. Carracedo, M.R. Furtado, D. Syndercombe Court, P.M. Schneider, The SNPforConsortium, evaluation of the Genplex SNP typing systems and a 49plex forensic marker panel, Forensic Sci. Int. Genet. 1 (2007) 180-185.

[16] C. Tomas, M. Stangegaard, C. Børsting, A.J. Hansen, N. Morling, Typing of 48 autosomal SNPs and amelogenin with GenPlex SNP genotyping system in forensic genetics, Forensic Sci. Int. Genet. 3 (2008) 1-6.

[17] M. Stangegaard, T.G. Frøslev, R. Frank-Hansen, S.S. Lauersen, M. Jørgensen, A.J. Hansen, N. Morling, Automated extraction of DNA and PCR setup using a Tecan Freedom EVO(R) liquid handler, Forensic Sci. Int. Genet., Suppl. Ser. 2 (2009) 74-76.

[18] J. Tukey, Explanatory Data Analysis, Addison-Wesley Publishing Co., 1977.

[19] P. Gill, Application of low copy number DNA profiling, Croat. Med. J. 42 (3) (2001) 229-232. 